Research Article

Cellular, Molecular and Developmental Genetics

\title{
Anti proliferative and apoptotic effects on pancreatic cancer cell lines indicate new roles for ANGPTL8 (Betatrophin)
}

\author{
Fatemeh Taherkhani ${ }^{1}$, Kamran Mousavi Hosseini ${ }^{1}$, Sanaz Zebardast ${ }^{2}$, Koorosh Goodarzvand Chegini ${ }^{2}$ and \\ Nematollah Gheibi ${ }^{2}$ \\ ${ }^{1}$ Iranian Blood Transfusion Organization, Research Center, Tehran, Iran. \\ ${ }^{2}$ Cellular and Molecular Research Center, Research Institute for Prevention of Non-Communicable \\ Diseases, Qazvin University of Medical Sciences, Qazvin, Iran.
}

\begin{abstract}
Despite considerable advances, the treatment of pancreatic cancer (PC) still requires much effort. Unusual regulation of the Wnt and apoptotic signaling pathways is widespread in cancer incidence. For instance, the WIF1 (Wnt inhibitory factor 1) gene is down-regulated in many cancers. The purpose of this study was to determine the effects of recombinant Betatrophin, a recently discovered hormone, on MiaPaca-II and Panc-1 pancreatic cell lines. Various concentrations of Betatrophin were added to MiaPaca-II and Panc-1 pancreatic cell lines during periods of 24 , 48, and $72 \mathrm{~h}$. The MTT assay was applied to investigate cell proliferation after treatment. The rate of apoptotic cells was assessed using double-staining flow cytometry, and the expression levels of the WIF1 gene and Bcl2 protein was observed by real-time PCR and western blotting, respectively. The findings of this study suggest that Betatrophin has an anti-proliferative effect on both MiaPaca-II and Panc-1 cell lines, in line with the up-regulation of WIF1 as a tumor suppressor gene. Moreover, the induction of apoptosis by ANGPTL8 occurred by the down-regulation of Bcl2. Thus, Betatrophin can be proposed as a potential therapeutic drug for treating pancreatic cancer.
\end{abstract}

Keywords: Betatrophin, Wnt, WIF1, Bcl2, pancreatic cancer.

Received: June 15, 2019; Accepted: May 31, 2020.

\section{Introduction}

Pancreatic cancer is one of the most fatal types of cancer. Since this cancer does not have an early prognosis, just under $20 \%$ of the patients live for more than one year after diagnosis (Bailey et al., 2016; Waddell et al., 2015). There are some factors that lead to the reduced survival rate of this disease. One is the difficulty in diagnosis during the early stages of the disease. Moreover, tumors progress rapidly while having few specific associated symptoms, and different pancreatic cancers show different responses to related drugs. Although there has been a progression towards figuring out the histological characteristics and molecular mechanisms underlying cancer development, studies showing favorable responses to available drugs continue to be rare. As a result, the survival chances of patients have not significantly improved (Siegel et al., 2013; Sahmani et al., 2016). A major obstacle for following a better treatment plan has been the heterogeneity of these cancers. This is because of the vast amount of somatic mutations acquired during the development of a tumor, and the different consequences of

Send correspondence to Nematollah Gheibi. Qazvin University of Medical Sciences, Cellular and Molecular Research Center, P.O.Box: 34199-15315, Qazvin, Iran, E-mail: gheibi_n@yahoo.com these mutations on cell signaling pathways (Sousa et al., 2013; Hidalgo et al., 2015).

The Wnt signaling pathway is responsible for controlling progress such as embryonic development, cell proliferation, polarization, cell fate, and the process of renewing in stem cells (Kudo, 2010). It has been indicated that this pathway has a decisive role in numerous malignancies, including breast cancer (Geyer et al., 2011), colon cancer (Vermeulen et al., 2010), leukemia (Luis et al., 2012), gastric cancer (Yong et al., 2016), esophageal cancer (Zhang et al., 2016a), and HCC 7 (Fatima et al., 2012), for instance. A role for the Wnt signaling pathway has also been reported in pancreas development (Hebrok, 2003; Dessimoz et al., 2005; Murtaugh et al., 2005, Papadopoulou and Edlund, 2005; Heiser et al., 2006). During early pancreatic development, incorrect activation of Wnt signaling causes imperfect development of this organ (Heller et al., 2002; Heiser et al., 2006).

Expression of the Wnt inhibitory factor 1 (WIF1) gene prevents receptor interactions and induces $\beta$-catenin degradation by binding directly to Wnt ligands situating outside the cell. Down-regulation of WIF1 has been reported prostate, breast, lung, and bladder cancers. Silencing of the WIF1 gene due to promoter hyper-methylation has been revealed in gastrointestinal, lung and bladder cancers (Taniguchi et al., 2005; Urakami et al., 2006; Yoshino et al., 2009; Rahmani et al., 
2017). It has also been observed that stimulation of WIF1 activity in cancer cells allowed to treat some malignant cancers (Ng et al., 2014). Although, activation of the Wnt pathway seems to be involved in pancreatic cancer (Wang et al., 2009), the expression and precise function of WIFl in pancreatic cancer progression have not been determined so far.

Apoptosis is a vital biological process that controls homeostasis and the dynamic balance between cell proliferation and cell death (Tabas and Ron, 2011), and the Bcl2 gene family with about 25 members plays a key role in the regulation of the intrinsic or mitochondrial apoptotic pathway. However, for the understanding of the apoptotic effect in pancreatic cancer cell lines clarification is needed on the regulation of the pro-apoptotic gene Bax and the anti-apoptotic gene $B c l 2$, which play a significant role in the intrinsic pathway of apoptosis.

Betatrophin, also known as angiopoietin-like protein (ANGPTL8), is a recently identified circulating protein that is mostly produced in the liver and adipose tissues. The human Betatrophin gene has four exons encoding a protein with 198 amino acids. In various studies, its role has been determined in glucose and lipid metabolism, metabolic diseases (Crujeiras et al., 2016), polycystic ovary syndrome (PCOS) (Calan et al., 2016), adriamycin cardiomyopathy (Chen et al., 2016b), and renal dysfunction (Chen et al., 2016a).

The focus of this study was to assess its effects on cell proliferation and apoptosis in the MiaPaca-II and Panc-1 as pancreatic cancer cell lines treated with different concentrations of Betatrophin. The effects of Betatrophin on Wnt and apoptosis signaling pathways was assessed by measuring the expression level of WIF1 as a tumor suppressor gene by real-time PCR, and the expression of $\mathrm{Bcl} 2$ protein by western blot analysis.

\section{Material and Methods}

\section{Cloning of Betatrophin}

Betatrophin was cloned using the PET28 plasmid as vector for transformation of $E$. coli BL21 cells. The procedures of cloning and purification are described in our previous study (Gholami et al., 2017).

\section{Cell culture}

The human pancreatic cancer cell lines MiaPaca-II and Panc-1 were purchased from the Pasteur Institute of Iran and cultured in T-25 flasks (Jet Biofil Flask) using 4-6 mL of DMEM-high glucose medium containing 10\% fetal bovine serum (Gibson,26140-079) and 1\% antibiotic of penicillin-streptomycin (Gibson,15140-122). They were cultured at $37{ }^{\circ} \mathrm{C}$ under $5 \% \mathrm{CO}_{2}$ atmosohere. When cells reached $80 \%$ confluency in the subculture, the overlying medium was removed, and the cells were washed two times with 1 $\mathrm{mL}$ PBS. After adding trypsin-EDTA 0.25\% (Gibson, 25200-056), the cells were incubated for 2-3 min before adding $3 \mathrm{~mL}$ of DMEM medium to neutralize the trypsin effect. They were transferred to $15 \mathrm{~mL}$ Falcon tubes and centrifuged for $7 \mathrm{~min}$ at $1700 \mathrm{rpm}$. The supernatant medium was removed, new medium was added to the pelleted cells, and these were then transferred to incubation flasks. For freezing, $1 \mathrm{~mL}$ of freezing medium (5-10\% DMSO with $90-95 \%$ FBS) was used.

\section{Cell toxicity assessment by MTT assay}

Cell viability was tested using the colorimetric [3-(4, 5-dimethylthiazol-2yl-)-2,5-diphenyl tetrazolium bromide] tetrazolium reduction assay (MTT). The MiaPaca-II and Panc- 1 cell lines were seeded at a concentration of $510^{3}$ cells/well and incubated for $24 \mathrm{~h}$. After termination of the incubation period, the cells were exposed to $200 \mu \mathrm{L}$ of increasing concentrations of Betatrophin $(5,10,20,40,50,75,100$, $125,150 \mathrm{pg} / \mathrm{mL}$ ) for 24,48 and $72 \mathrm{~h}$. After $24 \mathrm{~h}$, the overlying medium was removed, and $180 \mu \mathrm{L}$ of new medium was added to each well. At the end of the treatment period, the medium as removed and $20 \mu \mathrm{L}$ of MTT (Sigma, Germany) was added to each well, followed by incubation for $4 \mathrm{~h}$ at 37 ${ }^{\circ} \mathrm{C}$ in the dark. After incubation, the MTT solution was removed and replaced with $200 \mu \mathrm{L}$ DMSO. The cells were then incubated for $10 \mathrm{~min}$ in a shaking incubator. Glycine buffer was added and absorbance was evaluated at $570 \mathrm{~nm}$ in an ELISA plate reader. The assay was performed in triplicate.

\section{Apoptotis assay via flow cytometry}

Assessment of apoptotic cells was done using the annexin V/PI double-staining flow cytometry detection kit (Biolegend). After culturing MiaPaca-II and Panc-1 cell lines and treating them with $150 \mathrm{M}$ concentrations of Betatrophin for 24, 48 and $72 \mathrm{~h}$, the cells were trypsinized and collected by centrifugation $(350 \times g, 5 \mathrm{~min})$. Annexin-V and PI conjugated with FITC were added to the cells, and they were incubated at room temperature for $15 \mathrm{~min}$. The fluorescence distribution was recorded in a two-color dot blot analysis, and the percentage of fluorescent cells was determined.

\section{RNA extraction and cDNA synthesis}

Total RNA of treated and untreated MiaPaca-II and Panc-1 cells was extracted using the BioFACT kit (Cat.No.RP101-050/RP101-100; South Korea) according to the manufacturer's guidelines. Quantity and purity of the extracted RNA was assessed in a Nanodrop spectrophotometer at the wavelength range of $90-320 \mathrm{~nm}$. cDNA was synthesized using the BioFACT kit (Cat.No.BR631-096) according to the manufacturer's instruction. The quality of the synthesized cDNA was assessed using Nanodrop spectrophotometry and gel electrophoresis.

\section{Real-time PCR expression analysis of the WIF1 gene}

The effects of Betatrophin on WIFl gene expression were assessed by real-time PCR. Primers were obtained from Macrogen (South Korea). Their sequences were: for GAPDH 5- CAA TGACCCCTTCATTGACC -3 and 5TGGAAGATGGTGATGGGATT-3; and for WIF-1 5-CC GAAATGGAGGCTTTTGTA-3 and 5-TGGTTGAG CAGTTTGCTTTG-3. Amplification was conducted in 20 
$\mu \mathrm{L}$ of SYBR Green PCR Master Mix (qPCRBIO SyberGreen Mix Separate-Rox (NGS2X)) under the following conditions: initial denaturation at $95^{\circ} \mathrm{C}$ for $15 \mathrm{~min}, 40$ cycles at $95{ }^{\circ} \mathrm{C}$ for $20 \mathrm{~s}$, annealing at $60{ }^{\circ} \mathrm{C}$ for the $30 \mathrm{~s}$ and extension at $72{ }^{\circ} \mathrm{C}$ for $30 \mathrm{~s}$. Data were analyzed by the Pfaffl method, and the graphs were drawn by REST software 2009.

\section{Expression of of $B c / 2$ by western blot analysis}

MiPaca-II and Panc-1 cells were seeded and incubated for $24 \mathrm{~h}$ and then treated with a $150 \mu \mathrm{M}$ solution of Betatrophin. Total protein extracts of the two cell lines were produced after 24, 48, and $72 \mathrm{~h}$ of treatment times using cell lysis buffer. Equal quantities of protein $(50 \mu \mathrm{g})$ were resolved by SDS-PAGE and gels were transferred to nitrocellulose membranes. Non-specific binding sites were blocked by incubation in blocking buffer (PBS containing $0.1 \%$ Tween 20 and $5 \%$ non-fat dry milk) for $24 \mathrm{~h}$ at $4{ }^{\circ} \mathrm{C}$. After washing the membranes twice, they were immunoblotted using the anti- $\beta$ actin, anti-Bcl-2 primary antibodies at $4{ }^{\circ} \mathrm{C}$ overnight and then incubated with the corresponding HRP conjugated secondary antibodies for $1 \mathrm{~h}$ at room temperature. Western blot bands were detected using an enhanced chemiluminescence (ECL) detection system (GeneGnome $X R Q$ - Chemiluminescence imaging). Band intensities were quantified and normalized to $\beta$-actin using the NIH ImageJ software.

\section{Results}

\section{Viability assay by MTT}

MiaPaca-II and Panc-1 cell lines were treated with several concentrations of Betatrophin and their viability was assessed by MTT assay. As shown in Figure 1A-C, the cell viability of both treated cell lines was decreased at the concentrations of $>75 \mathrm{pg} / \mathrm{mL}$ at all treatment times $(24,48$, and $72 \mathrm{~h})$.

\section{Apoptotic effect of Betatrophin}

The apoptotic effect of Betatrophin on MiaPaca-II and Panc-1 cell lines was assessed by double-staining AnnexinV/PI flow cytometric analysis. As illustrated in Figure 2A-L the dot-plot data for 24,48 , and $72 \mathrm{~h}$ treatment times show the occurrence of apoptosis for both cell lines treated with $150 \mathrm{pg} / \mathrm{mL}$ of Betatrophin. The overall percentage values of Betatrophin that induced apoptosis in early and late apoptotic cell populations at the three treatment times are shown in Figure 3.

\section{Expression changes of WIF1}

Expression of the WIF1 gene was compared in both treated and untreated cells. GAPDH was considered as an internal control for normalization. As shown in Figure 4A and $\mathrm{B}$, the expression of WIFI in both cell lines increased in comparison to control in a concentration-dependent manner.
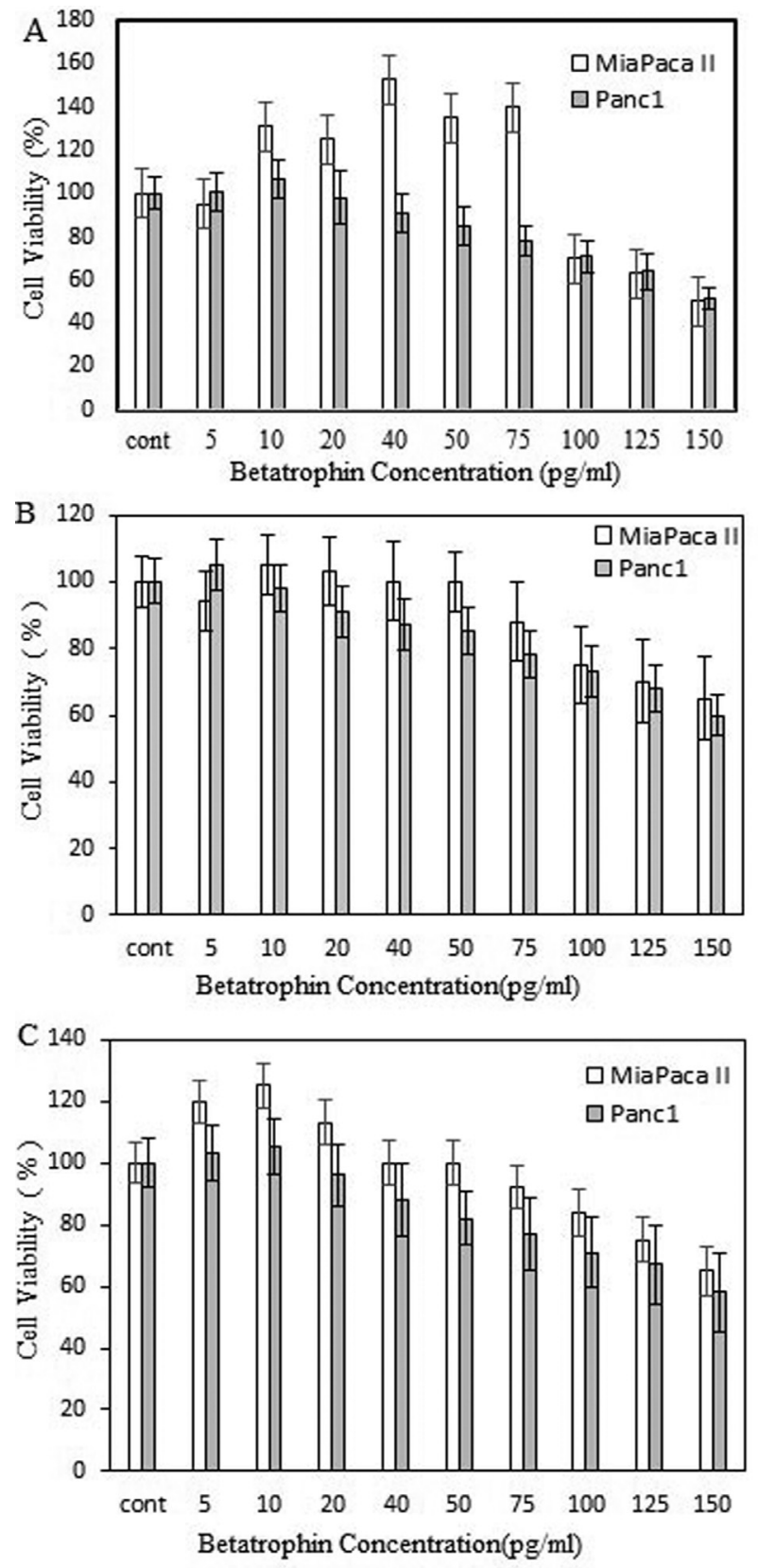

Figure 1 - Cytotoxic effect of Betatrophin concentrations on MiaPaca II and Panc-1 human pancreatic cancer cell lines. The percentage of cell viability was measured by MTT assay at $24 \mathrm{~h} \mathrm{(A),} 48 \mathrm{~h}(\mathrm{~B})$, and $72 \mathrm{~h}(\mathrm{C})$.

\section{Changes Bcl-2 protein levels}

For further analysis of apoptosis in Betatrophin-treated MiaPaca-II and Panc-1 cells, Bcl2 expression was assessed, as this is the main apoptosis-related gene. The protein level of Bcl2 was measured before and after treatment with $150 \mathrm{M}$ Betatrophin at 24, 48 , and $72 \mathrm{~h}$. We found that the level of anti-apoptotic protein Bcl-2 was dramatically reduced in both pancreatic cell lines (Figure 5). 


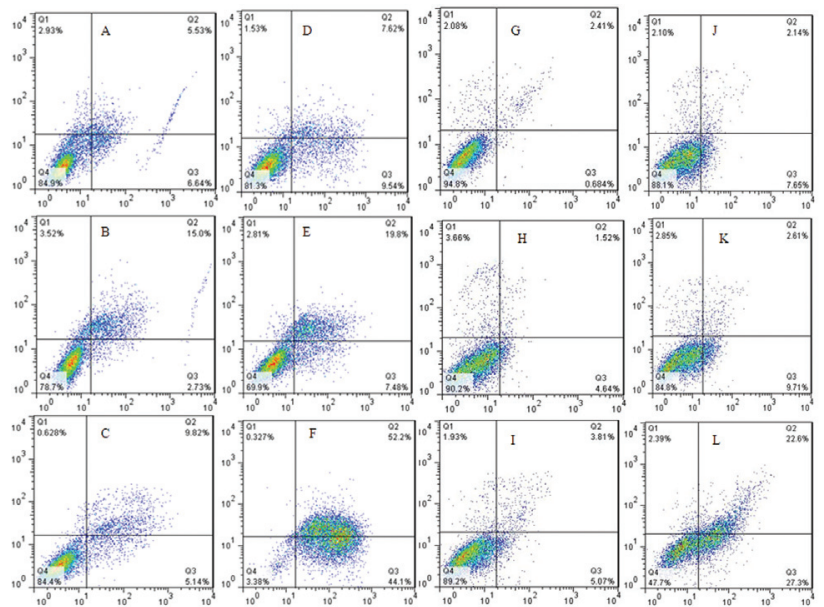

Figure 2 - Effect of different concentration of Betatrophin on apoptosis. Annexin V/PI double-staining flow cytometric assay of MiaPaca-II (A-F) and Panc-1 (G-L) pancreatic cancer cell lines after treatment with 150 $\mathrm{pg} / \mathrm{mL}$ Betatrophin on. (A and G) Untreated cells at $24 \mathrm{~h}$; (B and H) untreated cells at $48 \mathrm{~h}$; (C and I) untreated cells at $72 \mathrm{~h}$; (D and J) treated cells at $24 \mathrm{~h}$. (E and K) treated cells at $4 \mathrm{8h}$; (F and L) treated cells after $72 \mathrm{~h}$.

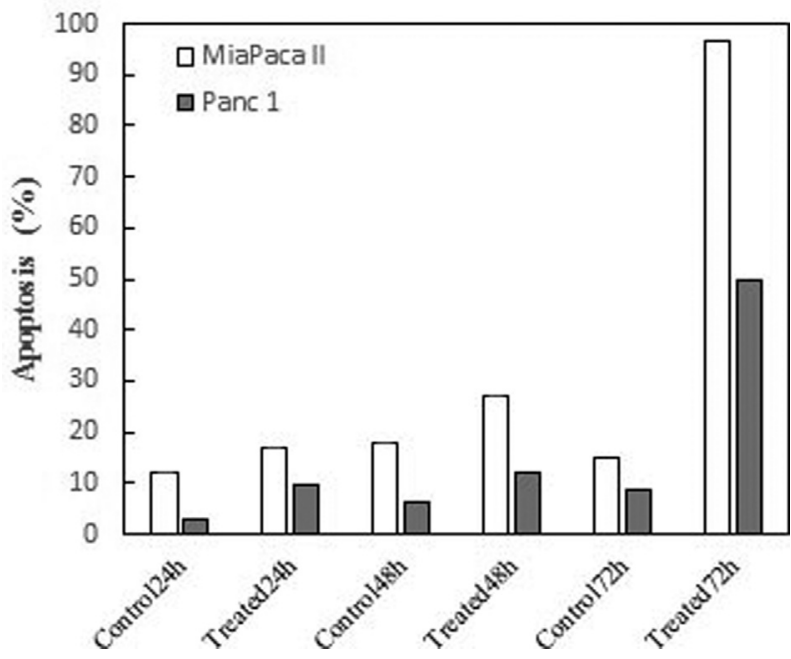

Figure 3 - Percentage of apoptosis induced by $150 \mathrm{pg} / \mathrm{mL}$ betatrophin on MiaPaca II and Panc-1 pancreatic cancer cell lines at 24 h, 48 h, and 72h treatment times.

\section{Discussion}

The results of the current study showed that Betatrophin induces anti-proliferative and apoptotic effects on the two pancreatic cancer cell lines MiaPaca-II and Panc-1. Inhibition of the Wnt signaling pathway was induced by the up-regulation of WIFI as a tumor-suppressor gene. Betatrophin-induced apoptosis was investigated through the downregulation of $\mathrm{Bcl} 2$ as an anti-apoptotic protein.

Numerous previous studies had reported that reducing the Wnt pathway targets cancer stem cells (Kim et al., 2018) and induces instant and substantial death in several cancer cell lines, including lung, breast, mesothelioma, and sarcoma, which all overexpress Wnt-1 (He et al., 2004). Inhibi-
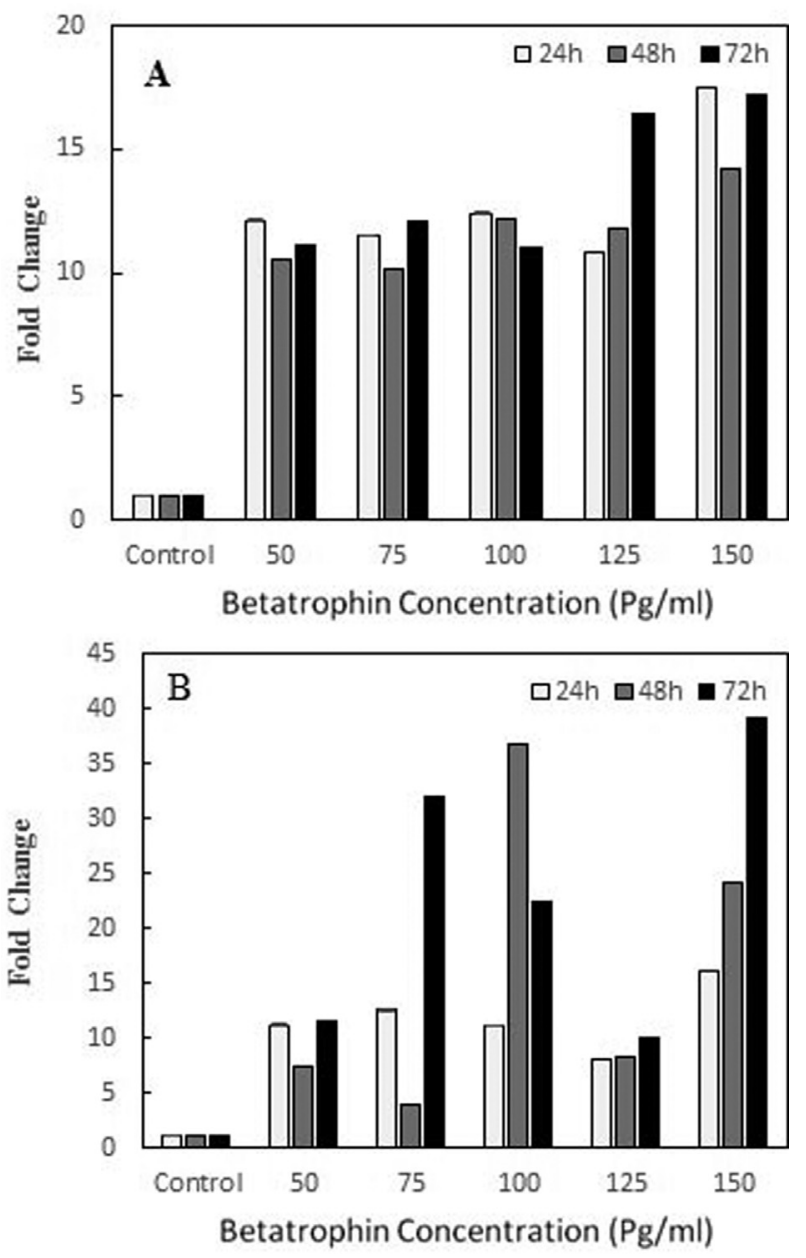

Figure 4 - Effect of different concentration of Betatrophin on the expression level of WIF1. The effects was asseded in MiaPaca-II (A) and Panc-1 (B) pancreatic cancer cell lines after $24 \mathrm{~h}, 48 \mathrm{~h}$ and $72 \mathrm{~h}$ treatment times.

tion of the Wnt signaling pathway resulted in suppression of cancer metastasis (Cao et al., 2017) and prevents the proliferation of cancer cells (Choi et al., 2010). Other findings suggest that this signaling pathwayis crucial inpancreatic cancerand may be a target for drug therapy (Garg et al., 2017, Dehghanifard et al., 2018). Poorly regulated $\mathrm{Wnt} / \beta$-catenin signaling has also been shown to be involved in the chemo-resistance of pancreatic cancer (Cui et al., 2012). A study done in 2017 showed that the microRNA-195 inhibits the spreading of pancreatic cancer cells by limiting the fatty acid synthase/Wnt signaling pathway. This study suggested that microRNA-195 can act as a tumor suppressor in the expansion of pancreatic cancer (Xu et al., 2017). A monoclonal antibody (OMP-18R5) that inhibits the Wnt signaling pathway in numerous tumors, including pancreatic ones, by targeting Frizzled receptors showed conspicuous synergy when combined with gemcitabine (Gurney et al., 2012). It was also demonstrated that Wnt-inhibitors, such as ethacrynic acid (EA), ciclopirox olamin (CIC), piroctone olamine (PO), and griseofulvin (GF) reduce the viability of a murine and a human pancreatic cell line (Wall and Schmidt- 


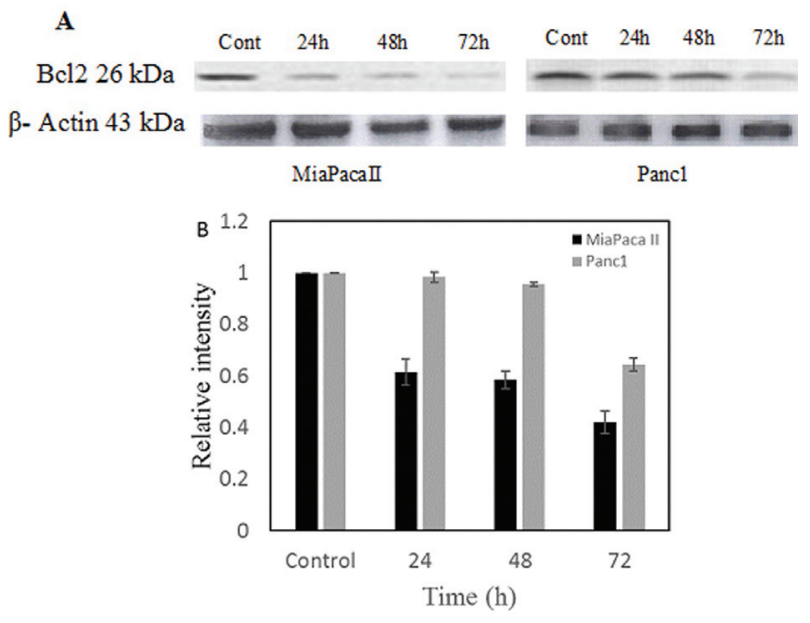

Figure 5 - Detection of Bcl2 protein by western blot analysis. (A) Bcl2 expression in MiaPacaII and Panc-1 panceratic cells at $24 \mathrm{~h}, 48 \mathrm{~h}$ and $72 \mathrm{~h}$ treatment times. $\beta$-Actin was used as loading control. (B) Bcl2 expression levels in untreated and treated cells were quantified by Image-J software and normalized to band intensity of $\beta$-actin.

Wolf, 2014). As shown here (Figure 1) Betatrophinrecombinant protein reduced cell viability of the MiaPaca-II and Panc- 1 cell lines in a dose-dependent manner. The expression levels of WIFI demonstrated regulatory effects of this tumor suppressor gene on the Wnt signaling pathway and thus, the anti-proliferation effect of Betatrophin (Figure 2).

ANGPTL proteins became attractive as prognostic or predictive indicators and as a new treatments for curing cancers (Carbone et al., 2018). ANGPTL8 (Betatrophin) ameliorates the inability of insulin in increasing glucose via the Akt-GSK3 $\beta$ or Akt-FoxO1 pathway in HepG2 cells (Guo et $a l ., 2016)$. It has been reported that this protein activates the ERK signal transduction pathway in hepatocytes, pancreatic $\beta$-cells, and adipocytes, causing down-regulating adipose triglyceride lipase (Zhang et al., 2016b). Betatrophin probably makes use of the macrophage receptor for regulating lipid/triglyceride metabolism, and the neuronal receptor mediating the signaling to pancreatic beta cells via nerves(Yi et al., 2014). It seems that increased levels of Betatrophin in serum in pancreatic cancer-associated diabetes (Susanto et al., 2016) may be a protective mechanism limiting the proliferation of cancer cells.

Applying flow cytometry to evaluate the apoptotic role of Betatrophin on MiaPaca-II and Panc-1 cell (Figures 3 and 4) showed that it increased the overall percentage of early and late apoptosis compared to control untreated cells, especially after 72 hours treatment time. Apoptosis related genes, including $B c l 2, B c l-x L$, and caspase-3 can be regulated by $\mathrm{NF}-\mathrm{\kappa B}$, thus inhibiting the apoptosis of pancreatic cells (Banerjee et al., 2005; Kunnumakkara et al., 2007). We found a significant decrease in the level of Bcl2 protein (Figure 5) indicating that induction of apoptosis by ANGPTL8 (Betatrophin) was achieved by down-regulation this protein. Higher expression of $B c l 2$ in cancer cells is known to lead to tumor progression by preventing apoptosis (Florou et al., 2013). Since the mitochondrial membrane potential is preserved by $B c l 2$, and its overexpressing causes a less pronounced decrease of mitochondrial depolarization, it is reasonable to assume that mitochondrial fission and fusion occur by reducing the level of $B c l 2$ in ANGPTL8-treated cells.

In the current study, higher expression of WIFl was observed after treatment with Betatrophin in the MiaPaca-II and Panc-1 pancreatic cancer cell lines. Decreased expression of WIF1 was reported in many cancers, such as gastrointestinal tract, kidney, glioblastoma, osteosarcoma, lung, pituitary, bladder, and oral cavity (Mazieres et al., 2004; Taniguchi et al., 2005; Urakami et al., 2006; Elston et al., 2007; Kawakami et al., 2009; Rubin et al., 2010; Lambiv et al., 2011; Paluszczak et al., 2015). When re-expressed, WIF1 can down-regulate the Wnt pathway and prevent cancer cell growth (Gao et al., 2009; Kawakami et al., 2009; Yee et al., 2010; Hirata et al., 2011; Ramachandran et al., 2012; Jiang et al., 2016). In line with our study, downregulation of the WIFl gene was observed in pancreatic cancer tissues, and this was attributed to hypermethylation of the WIF1 promoter region. Treatment with the demethylating agent 5-aza-20-deoxycytidine (5-aza-dC) re-established WIF1 expression in cancer cell lines. It was suggested that managing the Wnt pathway would be a probable target for treatment and/or prevention of gastrointestinal cancers like pancreatic cancer (Taniguchi et al., 2005; Azad et al., 2013). Furthermore, in pancreaticductal adenocarcinoma (PDA), HOX transcript antisense intergenic RNA (HOTAIR) regulates theexpressionof $W I F 1$, affecting the radiosensitivity ofpancreaticductal adenocarcinoma (Jiang et al., 2016).

Taken together, it is plausible to say that Betatrophin has an anticancer effect on the pancreatic cancer cell lines used in this study, MiaPaca-II and Panc-1, by inhibiting cell growth and increasing WIF1 gene expression, which subsequently reduces Wnt signaling as a decisive pathway in proliferation. Also, its anti-pancreatic cancer effect was shown by its induction of apoptosis and down-regulation of Bcl-2 as an anti-apoptotic protein.

\section{Acknowledgments}

Financial support from the Deputy of Research and Technology of Qazvin University of Medical Sciences is gratefully acknowledged.

\section{Conflict of interest}

The authors declare that there is no conflict of interest that could be perceived as prejudicial to the impartiality of the reported research.

\section{Author Contributions}

All authors contributed in all the steps of this study as followed: NG and KGC conceived the study and wrote the manuscript; FT and SZ conducted the experiments; KMH 
analyzed the data, and all authors read and approved the final manuscript version.

\section{References}

Azad M, Kaviani S, Noruzinia M, Mortazavi Y, Mobarra N, Alizadeh S, Shahjahani M, Skandari F, Ahmadi MH, Atashi A et al. (2013) Gene expression status and methylation pattern in promoter of P15INK4b and P16INK4a in cord blood CD34 (+) stem cells. Iran J Basic Med Sci 16:822-828.

Bailey P, Chang DK, Nones K, Johns AL, Patch AM, Gingras MC, Miller DK, Christ AN, Bruxner TJ and Quinn MC (2016) Genomic analyses identify molecular subtypes of pancreatic cancer. Nature 531:47-52.

Calan M, Yilmaz O, Kume T, Kocabas GU, Senses PY, Senses YM, Temur M and Calan OG (2016) Elevated circulating levels of betatrophin are associated with polycystic ovary syndrome. Endocrine 53:271-279.

Cao T, Xiao T, Huang G, Xu Y, Zhu JJ, Wang K, Ye W, Guan H, He J and Zheng D (2017) CDK3, target of miR-4469, suppresses breast cancer metastasis via inhibiting $\mathrm{Wnt} / \beta$-catenin pathway. Oncotarget 8:84917-84927.

Carbone C, Piro G, Merz V, Simionato F, Santoro R, Zecchetto C, Tortora G and Melisi D (2018) Angiopoietin-like proteins in angiogenesis, inflammation and cancer. Int J Mol Sci 19:e431.

Chen CC, Susanto H, Chuang WH, Liu TY and Wang CH (2016a) Higher serum betatrophin level in type 2 diabetes subjects is associated with urinary albumin excretion and renal function. Cardiovasc Diabetol 15:3.

Chen S, Chen J, Meng XL, Shen JS, Huang J, Huang P, Pu Z, McNeill NH and Grayburn PA (2016b) ANGPTL8 reverses established adriamycin cardiomyopathy by stimulating adult cardiac progenitor cells. Oncotarget 7:80391-80403.

Choi HY, Lim JE and Hong JH (2010) Curcumin interrupts the interaction between the androgen receptor and $\mathrm{Wnt} / \beta$-catenin signaling pathway in $\mathrm{LNCaP}$ prostate cancer cells. Prostate Cancer Prostatic Dis 13:343-349.

Crujeiras AB, Zulet MA, Abete I, Amil M, Carreira MC, Martínez JA and Casanueva FF (2016) Interplay of atherogenic factors, protein intake and betatrophin levels in obese-metabolic syndrome patients treated with hypocaloric diets. Int J Obesity 40:403-410.

Cui J, Jiang W, Wang S, Wang L and Xie K (2012) Role of $\mathrm{Wnt} / \beta$-catenin signaling in drug resistance of pancreatic cancer. Curr Pharmaceut Design 18:2464-2471.

Dehghanifard A, Kaviani S, Abroun S, Mehdizadeh M, Saiedi S, Maali A, Ghaffari S and Azad M (2018) Various signaling pathways in multiple myeloma cells and effects of treatment on these pathways. Clin Lymphoma Myeloma Leuk 18:311-320.

Dessimoz J, Bonnard C, Huelsken J and Grapin-Botton A (2005) Pancreas-specific deletion of $\beta$-catenin reveals Wnt-dependent and Wnt-independent functions during development. Curr Biol 15:1677-1683.

Elston MS, Gill AJ, Conaglen JV, Clarkson A, Shaw JM, Law AJ, Cook RJ, Little NS, Clifton-Bligh RJ, Robinson BG et al. (2007) Wnt pathway inhibitors are strongly down-regulated in pituitary tumors. Endocrinology 149:1235-1242.

Fatima S, Lee NP, Tsang FH, Kolligs FT, Ng IO, Poon RT, Fan ST and Luk JM (2012) Dickkopf 4 (DKK4) acts on Wnt/ $\beta$ catenin pathway by influencing $\beta$-catenin in hepatocellular carcinoma. Oncogene 31:4233-4244.

Gao Z, Xu Z, Hung MS, Lin YC, Wang T, Gong M, Zhi X, Jablon DM and You L (2009) Promoter demethylation of WIF-1 by epigallocatechin-3-gallate in lung cancer cells. Anticancer Res 29:2025-2030.

Garg B, Giri B, Majumder K, Dudeja V, Banerjee S and Saluja A (2017) Modulation of post-translational modifications in $\beta$-catenin and LRP6 inhibits Wnt signaling pathway in pancreatic cancer. Cancer Lett 388:64-72.

Geyer FC, Lacroix-Triki M, Savage K, Arnedos M, Lambros MB, MacKay A, Natrajan R and Reis-Filho JS (2011) $\beta$-Catenin pathway activation in breast cancer is associated with triple-negative phenotype but not with CTNNB1 mutation. Modern Pathol 24:209-231.

Gholami S, Chegini KG, Gheibi N, Mokhtarian K, Mohamadi M and Falak R (2017) Cloning, expression, and spectral analysis of mouse betatrophin. Med J Islamic Rep Iran 31:102-107.

Guo XR, Wang XL, Chen Y, Yuan YH, Chen YM, Ding Y, Fang J, Bian LJ and Li DS (2016) ANGPTL8/betatrophin alleviates insulin resistance via the Akt-GSK3 $\beta$ or Akt-FoxO1 pathway in HepG2 cells. Exp Cell Res 345:158-167.

Gurney A, Axelrod F, Bond CJ, Cain J, Chartier C, Donigan L, Fischer M, Chaudhari A, Ji M and Kapoun AM (2012) Wnt pathway inhibition via the targeting of Frizzled receptors results in decreased growth and tumorigenicity of human tumors. Proc Natl Acad Sci U S A 109:11717-11722.

He B, You L, Uematsu K, Xu Z, Lee AY, Matsangou M, McCormick F and Jablons DM (2004) A monoclonal antibody against Wnt-1 induces apoptosis in human cancer cells. Neoplasia 6:7-14.

Hebrok M (2003) Hedgehog signaling in pancreas development. Mech Dev 120:45-57.

Heiser PW, Lau J, Taketo MM, Herrera PL and Hebrok M (2006) Stabilization of $\beta$-catenin impacts pancreas growth. Development 133:2023-2032.

Heller RS, Dichmann DS, Jensen J, Miller C, Wong G, Madsen OD and Serup P (2002) Expression patterns of Wnts, Frizzleds, sFRPs, and misexpression in transgenic mice suggesting a role for Wnts in pancreas and foregut pattern formation. Dev Dynamics 225:260-270.

Hidalgo M, Cascinu S, Kleeff J, Labianca R, Lohr JM, Neoptolemos J, Real FX, Van Laethem JL and Heinemann V (2015) Addressing the challenges of pancreatic cancer: future directions for improving outcomes. Pancreatology 15:8-18.

Hirata H, Hinoda Y, Nakajima K, Kawamoto K, Kikuno N, Ueno K, Yamamura S, Zaman MS, Khatri G and Chen Y (2011) Wnt antagonist DKK1 acts as a tumor suppressor gene that induces apoptosis and inhibits proliferation in human renal cell carcinoma. Int J Cancer 128:1793-1803.

Jiang Y, Li Z, Zheng S, Chen H, Zhao X, Gao W, Bi Z, You K, Wang Y, Li W et al. (2016) The long non-coding RNA HOTAIR affects the radiosensitivity of pancreatic ductal adenocarcinoma by regulating the expression of Wnt inhibitory factor 1. Tumor Biol 37:3957-3967.

Kawakami K, Hirata H, Yamamura S, Kikuno N, Saini S, Majid S, Tanaka Y, Kawamoto K, Enokida H, Nakagawa M et al. (2009) Functional significance of Wnt inhibitory factor-1 gene in kidney cancer. Cancer Res 69:8603-8610.

Kim MS, Cho HI, Yoon HJ, Ahn YH, Park EJ, Jin YH and Jang YK (2018) JIB-04, A small molecule histone demethylase inhibitor selectively targets colorectal cancer stem cells by inhibiting the Wnt/ $\beta$-catenin signaling pathway. Sci Rep 8:6611-6623.

Kudo M (2010) Current status of molecularly targeted therapy for hepatocellular carcinoma: clinical practice. Int J Clin Oncol $15: 242-255$ 
Lambiv WL, Vassallo I, Delorenzi M, Shay T, Diserens AC, Misra A, Feuerstein B, Murat A, Migliavacca E, Hamou MF et al. (2011) The Wnt inhibitory factor 1 (WIF1) is targeted in glioblastoma and has a tumor suppressing function potentially by induction of senescence. Neuro-oncology 13:736-747.

Luis TC, Ichii M, Brugman MH, Kincade P and Staal FJ (2012) Wnt signaling strength regulates normal hematopoiesis and its deregulation is involved in leukemia development. Leukemia 26:414-426.

Mazieres J, He B, You L, Xu Z, Lee AY, Mikami I, Reguart N, Rosell R, McCormick F and Jablons DM (2004) Wnt inhibitory factor- 1 is silenced by promoter hypermethylation in human lung cancer. Cancer Res 64:4717-4720.

Murtaugh LC, Law AC, Dor Y and Melton DA (2005) $\beta$-catenin is essential for pancreatic acinar but not islet development. Development 132:4663-4674.

Ng RC, Matsumaru D, Ho AS, Garcia-Barcelo MM, Yuan ZW, Smith D, Kodjabachian L, Tam PK, Yamada G and Lui VC (2014) Dysregulation of Wnt inhibitory factor 1 (Wif1) expression resulted in aberrant Wnt- $\beta$-catenin signaling and cell death of the cloaca endoderm, and anorectal malformations. Cell Death Diff 21:978-989.

Paluszczak J, Sarbak J, Kostrzewska-Poczekaj M, Kiwerska K, Jarmuz-Szymczak M, Grenman R, Mielcarek-Kuchta D and Baer-Dubowska W (2015) The negative regulators of Wnt pathway - DACH1, DKK1, and WIF1 are methylated in oral and oropharyngeal cancer and WIF1 methylation predicts shorter survival. Tumor Biol 36:2855-2861.

Papadopoulou S and Edlund H (2005) Attenuated Wnt signaling perturbs pancreatic growth but not pancreatic function. Diabetes 54:2844-2851.

Rahmani T, Azad M, Chahardouli B, Nasiri H, Vatanmakanian M and Kaviani S (2017) Patterns of DNMT1 promoter methylation in patients with acute lymphoblastic leukemia. Int $\mathrm{J}$ Hematol Oncol Stem Cell Res 11:172-177.

Ramachandran I, Thavathiru E, Ramalingam S, Natarajan G, Mills WK, Benbrook DM, Zuna R, Lightfoot S, Reis A, Anant S et al. (2012) Wnt inhibitory factor 1 induces apoptosis and inhibits cervical cancer growth, invasion and angiogenesis in vivo. Oncogene 31:2725-2737.

Rubin EM, Guo Y, Tu K, Xie J, Zi X and Hoang BH (2010) Wnt inhibitory factor 1 decreases tumorigenesis and metastasis in osteosarcoma. Mol Cancer Therap 9:731-741.

Sahmani M, Vatanmakanian M, Goudarzi M, Mobarra N and Azad M (2016) Microchips and their significance in isolation of circulating tumor cells and monitoring of cancers. Asian Pac J Cancer Prev 17:879-894.

Siegel R, Naishadham D and Jemal A (2013) Cancer statistics, 2013. CA Cancer J Clin 63:11-30.

Sousa EMF, Vermeulen L, Fessler E and Medema JP (2013) Cancer heterogeneity - a multifaceted view. EMBO Rep 14:686-695.

Susanto H, Liu TY, Chen CC, Purnomo JD, Chen SF and Wang CH (2016) Increased serum levels of betatrophin in pancreatic cancer-associated diabetes. Oncotarget 7:42330-42337.

Taniguchi H, Yamamoto H, Hirata T, Miyamoto N, Oki M, Nosho K, Adachi Y, Endo T, Imai K and Shinomura Y (2005) Fre- quent epigenetic inactivation of Wnt inhibitory factor-1 in human gastrointestinal cancers. Oncogene 24:7946-7952.

Urakami S, Shiina H, Enokida H, Kawakami T, Tokizane T, Ogishima T, Tanaka Y, Li LC, Ribeiro-Filho LA, Terashima M et al. (2006) Epigenetic inactivation of Wnt inhibitory factor-1 plays an important role in bladder cancer through aberrant canonical Wnt/ $\beta$-catenin signaling pathway. Clin Cancer Res 12:383-391.

Vermeulen L, De Sousa E, Melo F, van der Heijden M, Cameron K, de Jong JH, Borovski T, Tuynman JB, Todaro M, Merz C et al. (2010) Wnt activity defines colon cancer stem cells and is regulated by the microenvironment. Nat Cell Biol 12:468-476.

Waddell N, Pajic M, Patch AM, Chang DK, Kassahn KS, Bailey P, Johns AL, Miller D, Nones K, Quek K and Quinn MC (2015) Whole genomes redefine the mutational landscape of pancreatic cancer. Nature 518:495-501.

Wall I and Schmidt-Wolf IG (2014) Effect of Wnt inhibitors in pancreatic cancer. Anticancer Res 34:5375-5380.

Wang L, Heidt DG, Lee CJ, Yang H, Logsdon CD, Zhang L, Fearon ER, Ljungman M and Simeone DM (2009) Oncogenic function of ATDC in pancreatic cancer through Wnt pathway activation and $\beta$-catenin stabilization. Cancer Cell 15:207-219.

Xu Z, Li C, Qu H, Li H, Gu Q and Xu J (2017) MicroRNA-195 inhibits the proliferation and invasion of pancreatic cancer cells by targeting the fatty acid synthase/Wnt signaling pathway. Tumor Biol 39: 1010428317711324.

Yee DS, Tang Y, Li X, Liu Z, Guo Y, Ghaffar S, McQueen P, Atreya D, Xie J, Simoneau AR et al. (2010) The Wnt inhibitory factor 1 restoration in prostate cancer cells was associated with reduced tumor growth, decreased capacity of cell migration and invasion and a reversal of epithelial to mesenchymal transition. Mol Cancer 9:162-166.

Yi P, Park JS and Melton DA (2014) Perspectives on the activities of ANGPTL8/betatrophin. Cell 159:467-468.

Yong X, Tang B, Xiao YF, Xie R, Qin Y, Luo G, Hu CJ, Dong H and Yang SM (2016) Helicobacter pylori upregulates Nanog and Oct4 via Wnt/ $\beta$-catenin signaling pathway to promote cancer stem cell-like properties in human gastric cancer. Cancer Lett 374:292-303.

Yoshino M, Suzuki M, Tian L, Moriya Y, Hoshino H, Okamoto T, Yoshida S, Shibuya K and Yoshino I (2009) Promoter hypermethylation of the p16 and Wif-1 genes as an independent prognostic marker in stage IA non-small cell lung cancers. Int J Oncol 35:1201-1209.

Zhang S, Wei Y, Zhang H, Li C, Cai K, Chen L, Sun X, Rong Z and Shi W (2016a) Functions of the Wnt/ $\beta$-catenin pathway in esophageal cancer. International J Clin Exp Med 9:4348-4355.

Zhang Y, Li S, Donelan W, Xie C, Wang H, Wu Q, Purich DL, Reeves WH, Tang D and Yang LJ (2016b) Angiopoietin-like protein 8 (betatrophin) is a stress-response protein that down-regulates expression of adipocyte triglyceride lipase. Biochim Biophys Acta Mol Cell Biol Lipids 1861:130-137.

Associate Editor: Rogério Margis

License information: This is an open-access article distributed under the terms of the Creative Commons Attribution License (type CC-BY), which permits unrestricted use, distribution and reproduction in any medium, provided the original article is properly cited. 